\title{
НОРМАТИВНО-ПРАВОВІ АСПЕКТИ ПРОТИДІї НЕЗАКОННОМУ ОБІГУ ВОГНЕПАЛЬНОÏ ЗБРОЇ
}

Біліченко В. В.

Метою cmammi $\epsilon$ з'ясування змісту нормативно-правових аспектів щодо протидіі незаконному обігу вогнепальної зброї в України. Актуальність обраної роботи передусім зумовлена поширенням таких суспільних явищ, як: збройні конфлікти на сході Україні, проведення Антитерористичної операції на Сході країни у 2014-2017 роках. 3 огляду на це досліджено питання нормативно-правових аспектів протидії незаконному обігу зброї в Україні станом натепер, а також з'ясувано вплив незаконного обігу вогнепальної зброї на криміногенний стан у країні. Проведено аналіз першопричин виникнення цієї проблеми, здійснено безпосередній пошук шляхів щодо їі вирішення, у процесі чого було розглянуто вітчизняну та міжнародну нормативно-правову базу (чинні закони України, постанови Кабінету Міністрів, накази Міністерства внутрішніх справ України, протоколи Конвенції Організації Об'єднаних Націй, ратифіковані Україною) щодо регулювання питань запобігання незаконному постачанню вогнепальної зброї, боєприпасів, а також встановлені основні джерела таких, як внутрішньодержавні так і зовнішні. 3 урахуванням закордонного досвіду нормативно-правового регулювання незаконного обігу вогнепальної зброї зроблені відповідні висновки щодо необхідності вдосконалення нормативно-правових аспектів для запобігання незаконному обігу вогнепальної зброї в Україні. У дослідженні також детально описано процедуру (етапи) отримання дозволу на зброю для осіб різних категорій: для працівників міністерств, інших центральних органів виконавчої влади, Національного банку України, підприємств, установ і організацій, а також цивільних осіб, щодо останніх наведений перелік низки документів, які необхідно надати до підрозділу дозвільної системи Міністерства внутрішніх справ. Автором надано дефініцію поняття «незаконний обіг зброї» та зазначено, що вирішенню цього питання, його врегулюванню та запобіганню таким проявам у суспільстві може сприяти вдосконалення законодавчої бази України.

Ключові слова: вогнепальна зброя, незаконний обіг, протидія, законодавче регулювання, громадська безпека, нормативно-правова база.

Bilichenko V. V. Regulatory aspects of combating illegal trafficking of firearms

The purpose of the article is to clarify the content of regulatory aspects of combating the illicit trafficking of firearms in Ukraine. The relevance of the selected work, first of all, is manifested in the existence of such social phenomena: armed conflicts in eastern Ukraine, the Anti-Terrorist Operation in the East in 2014-2017. With this in mind, the issue of regulatory and legal aspects of combating illicit trafficking in Ukraine as of today, as well as clarifying the impact of illicit trafficking in firearms on the criminal situation in the country. The analysis of the root causes of this problem, direct search for ways to solve it, during which the domestic and international legal framework was considered (current laws of Ukraine, resolutions of the Cabinet of Ministers, Orders of the Ministry of Internal Affairs of Ukraine, protocols of the UN Convention ratified by Ukraine), on the regulation of the prevention of illicit supply of firearms, ammunition, as well as the main sources such as domestic and foreign. Taking into account the foreign experience of regulatory and legal regulation of illicit trafficking in firearms, the relevant conclusions have been made on the need to improve the regulatory and legal aspects of illicit trafficking in firearms in Ukraine. The study also describes in detail the procedure (stages) for obtaining a weapon permit for different categories of persons: employees of ministries, other central executive bodies, the National Bank of Ukraine, enterprises, institutions and organizations, as well as civilians. must be submitted to the unit of the permit system of the Ministry of Internal Affairs. The author provides a definition of the concept of "illicit trafficking in weapons" and noted that to address this issue, its settlement and prevention of such manifestations in society, may be to improve the legal framework of Ukraine.

Key words: firearms, illicit trafficking, counteraction, legislative regulation, public safety, normative-legal base.

Постановка проблеми та її актуальність. Суспільно-політична, економічна ситуація, зростання чисельності криміногенних елементів у суспільстві, збройні конфлікти на сході Україні, проведення Антитерористичної операції на Сході країни у 2014-2017 рр., слабка захищеність окремих ділянок українського кордону, формування злочинних груп і організацій стають передумовою для розмови про нелегальний обіг зброї у країні. Станом на 25 липня 2018 р., за інформацією Укра-

(c) Біліченко В. В., 2020 
їнської асоціації власників зброї, офіційно в руках українців зосереджено майже два млн одиниць зареєстрованої вогнепальної зброї, незареєстрованої приблизно така ж кількість. Громадянське суспільство виправдовує таку ситуацію необхідністю самозахисту, тому що висловлює недовіру до правоохоронної системи, а також натепер залишається невирішеним конфлікт на Сході України.

Мета статті полягає у з'ясуванні змісту нормативно-правових аспектів щодо протидії незаконному обігу вогнепальної зброї в України.

Аналіз останніх досліджень і публікацій. Проблема незаконного обігу вогнепальної зброї $\epsilon$ однією з основних у дослідженнях вітчизняних та закордонних учених. Окремі аспекти незаконного обігу вогнепальної зброї висвітлені в наукових працях із кримінального права, кримінального процесу, кримінології. Заслуговують на увагу праці таких учених: П.Д. Біленчука, Ю.М. Антоняна, С.В. Бобровика, М.І. Мельника, В.А. Мисливого, Ю.Г. Пономаренка, А.В. Савченка, Н.Ю. Осипова, В.Я. Тація й інших. Також досліджують питання незаконного обігу вогнепальної зброї державні інституції (Національний інститут стратегічних досліджень) та закордонні організації, наприклад, Small Arms Survey - швейцарський незалежний науковий центр.

Виклад основного матеріалу. Уважаємо, що натепер в українському законодавстві немає закону, де були б закріплені поняття «зброя» та «обіг зброї». Ускладнює регулювання цього питання відсутність єдиного закону, який реґламентував би виготовлення, купівлю, володіння вогнепальною зброєю, додатково доречним було б створення такого органу, як єдиний центральний державний реєстр вогнепальної зброї цивільного населення. У процесі численних досліджень виявлено, що натепер багато вогнепальної зброї перебуває в незаконному обігу. Основними причинами цього $є$ :

залишки значного обсягу вогнепальної зброї, що зосередилися у країні після розпаду Радянського Союзу;

початок збройного конфлікту у 2014 р. на території Донецької та Луганської областей, що також призвів до розграбування збройних запасів держави (а також безконтрольність вивозу зброї під час ротацій);

наявність неконтрольованих ділянок кордону держави, що сприяє незаконному переправленню зброї.

Процес оцінки незаконного обігу вогнепальної зброї $\epsilon$ досить складним і натепер недосконалий, що не дозволяє повною мірою пересвідчи- тися в успіхах роботи правоохоронних органів із протидії та припинення незаконного поширення вогнепальної зброї. До основних джерел незаконного постачання вогнепальної зброї, боєприпасів відносять транскордонну торгівлю та перепродаж внутрішніх запасів.

У низці законів України будь-яким чином закріплені окремі питання щодо цього. Прикладом можуть слугувати Закон України «Про мисливське господарство та полювання» (редакція від 10 березня 2017 р.) [6], Закон України «Про поводження з вибуховими матеріалами промислового призначення» (редакція від 18 грудня 2017 р.) [1], Закон України «Про ліцензування видів господарської діяльності» (редакція від 28 вересня 2017 р.) [5].

Постановою Кабінету Міністрів України «Положення про дозвільну систему» встановлено перелік предметів, що входять до компетенції дозвільної системи, такими $\epsilon$ вогнепальна зброя, холодна зброя, пневматична зброя калібру понад 4,5 мм, швидкість польоту кулі яких понад 100 м/с, пристрої вітчизняного виробництва тощо [4].

Ще одним нормативно-правовим актом, що регулює обіг зброї, $є$ наказ Міністерства внутрішніх справ України від 21 серпня 1998 р. № 622, яким затверджено «Інструкцію про порядок виготовлення, придбання, зберігання, обліку, перевезення та використання вогнепальної, пневматичної, холодної і охолощеної зброї, пристроїв вітчизняного виробництва для відстрілу патронів, споряджених гумовими чи аналогічними за своїми властивостями метальними снарядами несмертельної дії, та патронів до них, а також боєприпасів до зброї, основних частин зброї та вибухових матеріалів» [2].

3 огляду на викладений вище перелік нормативно-правових актів, незважаючи на те, що вони містять деякі положення щодо питання «незаконного обігу зброї», усе одно немає чіткого тлумачення цього поняття. Серед міжнародних документів, що ратифіковані Україною, «Протокол проти незаконного виготовлення та обігу вогнепальної зброї, її складових частин і компонентів, а також боєприпасів до неї, який доповнює Конвенцію Організації Об'єднаних Націй проти транснаціональної організованої злочинності», що набрав чинності в Україні 4 липня 2013 р., $з$ метою забезпечення міжнародного співробітництва на регіональних та глобальних рівнях у недопущенні й припиненні незаконного виготовлення й обігу вогнепальної зброї. Загальні положення цього документа закріплюють основні терміни та тлумачать їх. Так, у ст. 3 під незаконним обігом розу- 

та науково-методичне забезпечення

міють ввіз (вивіз), придбання, продаж, доставку, переміщення або передачу вогнепальної зброї, ii складових частин і компонентів, а також боєприпасів до неї з території або територією однієї держави-учасниці на територію іншої держави-учасниці, якщо будь-яка із зацікавлених держав-учасниць не надає дозволу на це відповідно до положень цього Протоколу або якщо вогнепальна зброя не має маркування [7].

У наш час уряд докладає багато зусиль, що мають на меті боротьбу з незаконними потоками зброї, але вони $\epsilon$ досить розпорошені. Нормативно-правова база України, якою реґламентуються та встановлюються процеси з використання та володіння вогнепальною зброєю, є недосконалою та суперечливою. За результатами аналізу нормативно-правових аспектів даного питання можна зазначити таке: протягом 1998-2014 рр. депутатами Верховної Ради та членами Кабінету Міністрів України було подано до Парламенту приблизно 14 законопроєктів щодо регулювання обігу вогнепальної зброї, але до істотних змін це не привело.

Наказ Міністерства внутрішніх справ № 622 від 21 серпня 1998 р. реґламентує ціль придбання вогнепальної зброї для міністерства й інших центральних органів виконавчої влади, підприємств, установ, організацій і суб'єктів господарювання. Відповідно до п. 9.1 розд. 2 ч. 9, вогнепальна зброя та бойові припаси до неї можуть придбаватися для захисту життя, здоров'я та майна громадян. Цим наказом також встановлена процедура видачі дозволу на зброю міністерствам, іншими центральним органам виконавчої влади, підприємствам, установам, організаціям [9].

По-перше, відповідно до п. 9.2, такі дозволи видаються тільки за наявності законодавчого або іншого нормативно-правового акта про надання права працівникам міністерств, інших центральних органів виконавчої влади, Національного банку України, підприємств, установ і організацій користуватися нею під час виконання службових обов'язків, лише після вивчення ними матеріальної частини зброї, правил поводження з нею, іiі застосування та використання, що здійснюється в пунктах вивчення матеріальної частини зброї, спеціальних засобів, правил поводження з ними та їх застосування, після складання заліку й отримання довідки про вивчення матеріальної частини зброї, спеціальних засобів, правил поводження з ними та їх застосування.

По-друге, що стосується отримання такого дозволу цивільною особою, то цей процес $є$ більш ускладненим. Він складається з декількох етапів:
1. Придбання сейфа для належного зберігання зброї та боєприпасів.

2. Проходження медичної комісії для отримання медичної довідки (форма 127/о).

3. Проходження навчання та складання іспиту із знань матеріальної частини зброї, правил поводження з нею, іï застосування, для отримання відповідної довідки.

4. Подача низки документів до підрозділу дозвільної системи Міністерства внутрішніх справ України, такими $є:$

- заява про видачу дозволу. За місцем проживання заявника, заповнюється у відділі Міністерства внутрішніх справ;

- заповнена картка-заявка;

- медична довідка, що посвідчує стан здоров'я відповідним для отримання такого дозволу;

- копія договору страхування;

- документ, що посвідчує проходження курсів із вивчення матеріальної частини зброї, правил іï застосування і поводження з нею;

- довідка про відсутність судимості;

- паспорт та копія;

4 фотокартки (3 x 4);

платіжний документ про сплату за реєстрацію зброї.

5. Подача всіх документів інспекторові, що здійснює їх перевірку, яка триває 30 днів.

6. Отримання дозволу на зброю (термін його дії - 3 місяці).

7. Купівля зброї в офіційно зареєстрованих магазинах зброї.

8. Звернення до відділу дозвільної системи, де інспектор звіряє номери зброї відповідно до документів, після чого отримуємо пластиковий дозвіл на право зберігання та носіння зброї.

Що ж, незважаючи на наявність таки окремих положень для врегулювання цього питання, наявна нагальна необхідність ухвалення окремого закону для запобігання незаконному обігу зброї серед криміногенних елементів. Так, у ст. ст. 263, 263-1 Кримінального кодексу передбачено відповідальність за незаконний обіг, покарання у вигляді позбавлення волі на строк від п'яти до десяти років [3].

Статистичні дані Єдиного реєстру державної реєстрації доводять, що в протягом 2014-2017 рр. тільки в місті Києві кількість таких судових вироків збільшилась на $55 \%$.

Для приватних осіб існує заборона на володіння короткоствольною вогнепальною зброєю, зокрема пістолетами й компактними автоматичними пістолетами, відповідно до постанов Мініс- 
терства внутрішніх справ України. Деякі категорії громадян (депутати Верховної Ради України, прокурори, судді, журналісти) мають право на володіння зброєю несмертельної дії. Громадяни віком від 21 року можуть володіти гладкоствольною вогнепальною зброєю (мисливська гладкоствольна рушниця), особи віком від 25 років також можуть володіти ліцензією на нарізну зброю (мисливська рушниця тощо), яка підлягає державній реєстрації. Щодо кількості зброї, якою може володіти особа, обмежень не існує. Реєстрація зброї - ускладнений і обтяжливий процес, важливим чинником якого $\epsilon$ ціновий показник продажу цієї зброї, що встановлює держава, поза увагою залишаються тенденції ринку поза межами України.

Висновки. У підсумку варто зазначити, що треба розмежовувати поняття «незаконний обіг зброї» на два види: по-перше, учинення адміністративних правопорушень, а також порушення інших заборон адміністративного законодавства; по-друге, «незаконний обіг зброї» варто розглядати як порушення кримінально-правових заборон, що спричиняє кримінальну відповідальність, сукупність цих чинників дозволяє дати загальне визначення поняття «незаконний обіг зброї». Отже, під незаконним обігом зброї варто розуміти всякі дії зі зброєю, винятком є використання за цільовим призначенням, які вчиняються без законного дозволу, після яких настає адміністративна або кримінальна відповідальність.

Уважаю, вирішенню цього питання, його чіткому врегулюванню та запобіганню таким проявам у суспільстві сприятиме вдосконалення законодавчої бази України щодо незаконного обігу зброї: ухвалення відповідного закону України, де буде визначено поняття «незаконний обіг вогнепальної зброї», його види, перелік, установлено чіткі норми притягнення до відповідальності.

\section{Література}

1. Про затвердження Правил безпеки під час поводження з вибуховими матеріалами промислового призначення : Закон України № 355, у редакції від 12 червня 2013 р. URL: https://zakon.rada.gov.ua/ laws/show/z1127-13 (дата звернення: 02.10.2020).

2. Інструкція про порядок виготовлення, придбання, зберігання, обліку, перевезення та використання вогнепальної, пневматичної, холодної i охолощеної зброї, пристроїв вітчизняного виробництва для відстрілу патронів, споряджених гумовими чи аналогічними за своїми властивостями метальними снарядами несмертельної дії, та патронів до них, а також боєприпасів до зброї, основних частин зброї та вибухових матеріалів : наказ МВС України від 21 серпня 1998 р. № 622. URL: http://zakon2. rada.gov.ua/laws/show/z0637- 98 (дата звернення: 02.10.2020).

3. Кримінальний кодекс України : Закон від 5 квітня 2001 р. № 2341-ІІІ. Відомості Верховної Ради України. 2001. № № 25-26. Сст. 263.

4. Положення про дозвільну систему : постанова Кабінету Міністрів України від 12 жовтня 1992 р. № 576. URL: http://zakon2.rada.gov.ua/laws/ show/576-92-п (дата звернення: 02.10.2020).

5. Про ліцензування видів господарської діяльності : Закон України від 2 вересня 2015 р. № 222-VIII. Відомості Верховної Ради України. 2015. № 23. Ст. 158 ; зі змінами станом на 1 березня 2017 p. URL: https://zakon.rada.gov.ua/laws/ show/222-19 (дата звернення: 02.10.2020).

6. Про мисливське господарство та полювання : Закон України від 22 лютого 2000 р. № 1478-ІІІ. Відомості Верховної Ради України. 2000. № 18. Ст. 132 ; із змінами станом на 7 лютого 2017 р. URL: https:// zakon.rada.gov.ua/laws/show/1478-14 (дата звернення: 02.10.2020).

7. Протокол проти незаконного виготовлення та обігу вогнепальної зброї, іiї складових частин і компонентів, а також боєприпасів до неї, який доповнює Конвенцію Організації Об'єднаних Націй проти транснаціональної організованої злочинності. Затверджено Резолюцією 55/255 Генеральної Асамблеї ООН від 31 травня 2001 p. URL: http://zakon2.rada.gov.ua/ laws/show/995_792 (дата звернення: 02.10.2020).

8. Щодо правових аспектів організації протидії незаконному обігу вогнепальної зброї : аналітична записка. Начіональний інстumym cmpameгічних досліджень. URL: http://www.niss.gov.ua/ articles/969 (дата звернення: 02.10.2020).

9. Про затвердження Інструкції про порядок виготовлення, придбання, зберігання, обліку, перевезення та використання вогнепальної, пневматичної, холодної і охолощеної зброї, пристроїв вітчизняного виробництва для відстрілу патронів, споряджених гумовими чи аналогічними за своїми властивостями метальними снарядами несмертельної дії, та патронів до них, а також боєприпасів до зброї, основних частин зброї та вибухових матеріалів : наказ Міністерства внутрішніх справ № 622 від 21 серпня 1998 р. URL: http: //zakon.rada. gov.ua/laws/show/z0637-98\#n231 (дата звернення: 02.10.2020)

Біліченко В. В., старший викладач кафедри тактикоспеціальної підготовки

Дніпропетровського державного університету внутрішніх справ

ПІВАЕННОУКРАӤНСБКИЙ ПРАВНИЧИЙ ЧАСОПИС 